\title{
The 22 Immutable Laws of Branding*
}

\author{
Ries Al ${ }^{* *}$, Ries Laura ${ }^{* * *}$
}

\begin{abstract}
The power of a brand is inversely proportional to its scope. When you put your brand name on several products, indeed, the line extension allows an increase in sales in the short term, but it undermines brand name in the mind of the consumer in the long term.

A brand should strive to own a word in the mind of the consumer. Once a word is precisely associated with a brand, it is almost impossible for a competitor to create some stronger associations.
\end{abstract}

There are no barriers to global branding. A brand should know no borders.

Keywords: Brand; Brand Management; Global Branding; Laws of Branding; Marketing Management

There are many basic laws in the brand-building process.

1. The Law of Expansion: the power of a brand is inversely proportional to its scope. When you put your brand name on several products, indeed, the line extension allows an increase in sales in the short term, but it undermines brand name in the mind of the consumer in the long term. Do you broaden the line in order to increase sales in the short term? Or do you keep a narrow line in order to build the brand in the mind and increase sales in the future? Do you build the brand today in order to move merchandise tomorrow? Or do you expand the brand today in order to move goods today and see the decline tomorrow?

The emphasis in most companies is on the short term. Line extension, megabranding, variable pricing and a host of other sophisticated marketing techniques are being used to milk brands rather than build them.

2. The Law of Contraction: a brand becomes stronger when you narrow its focus. When you offer too many things the quality of your product or service will be mediocre. The average McDonald's has 70 or 80 individual items on the menu. Half the employees are teenagers, not yet old or mature enough to handle the

\footnotetext{
* Summarized by permission from 'The 22 Immutable Laws of Branding. How to Build Your Product or Service into a World-Class Brand', Mark Plus Quarterly, August-October 1998

** Ries and Ries, Chairman (al@ries.com)

${ }^{* * *}$ Ries and Ries, Co-Founder (laura@ ries.com)

Ries Al, Ries Laura, The 22 Immutable Laws of Branding, Symphonya. Emerging Issues in Management (symphonya.unimib.it), n. 1, 2000-2001, pp. 30-34 
complexities of today's operations. And people wonder why the food and service aren't as good as when they just served hamburgers, French fries and soft drinks. (The original McDonald's menu had just 11 items including all sizes and flavours). They offer too many things and as a result the food and service is mediocre.

Good thing will happen when you narrow the focus.

3. The Law of Publicity: the birth of a brand is usually accomplished with publicity, not advertising. A new brand must be capable of generating favourable publicity in the media or it will not have a chance in the marketplace.

In the past, it may have been true that a beefy advertising budget was the key ingredient in the brand-building process. But what worked in the past doesn't necessarily work today. We live in an over-communicated society, where each of us gets hit with hundreds of commercial messages daily. Today brands are born, not made.

4. The Law of Advertising: once born, a brand will die unless kept alive with advertising. Publicity is a powerful tool, but sooner or later a brand outlives its publicity potential.

The process normally goes through two distinct phases. Phase one involves the introduction of the category.

Phase two concerns the rise of the company that pioneered the new category.

5. The Law of the Word: a brand should strive to own a word in the mind of the consumer. Once a word is precisely associated with a brand, it is almost impossible for a competitor to create some stronger associations.

If you want to build a brand, you must focus your branding efforts on owning a word in the prospect's mind. A word that nobody else owns.

6. The Law of Credentials: the crucial ingredient to the success of any brand is its claim to authenticity. Credentials are the collateral that you put up to guarantee the performance of your brand and that makes every other claim about your brand much more believable.

When you have the right credentials, your prospect is likely to believe almost everything you say about your brand.

7. The Law of Quality: quality is important to have, but brands are not built by quality alone. There is almost no correlation between success in the marketplace and success in comparative testing of brands. Whether it be taste tests, accuracy tests, reliability tests, durability tests or any other independent, objective thirdparty testing of brands.

Quality or rather the perception of quality resides in the mind of the buyer. If you want to build a powerful brand, you have to build a powerful perception of quality in the mind.

8. The Law of the Category: a leading brand should promote the category not the brand. The most important branding decision you will ever make is what to name your product or service. The most efficient, most productive, most useful aspect of branding is creating a new category. That's the way to become the first in a new 
category and ultimately the leading brand in a rapidly growing new segment of the market.

9. The Law of the Name: in the long run a brand is nothing more than a name. Don't confuse what makes a brand successful in the short term with what makes a brand successful in the long term. In the short term, a brand seeds a unique idea or concept to survive. In the long term, the unique idea or concept disappears. All that is left is the difference between your brand name and the brand name of your competitors.

10. The Law of Extensions: the easiest way to destroy a brand is to put its name on everything. The rise in line extensions is a company's natural instinct to copy the competition. There is the way many companies think. The competition must know something we don't know. Let's do the same thing.

One reason 90 percent of all new brands are line extensions is that management measures result with the wrong end of the ruler. They only measure the erosion of the core brand. And it's not just the erosion, it's also the lost opportunities.

11. The Law of the Fellowship: in order to build a category of product, a brand should accept the presence of other brands. Choice stimulates demand. Customers have choices, even when there is no competition. Competition increases the noise level and tends to increase sales in the category. Competition also broadens the category while allowing the brands to stay focused.

Customers respond to competition because choice is seen as a major benefit.

12. The Law of the Generic: one of the fastest routes to failure is giving a brand a generic name. In the past, companies thought they needed big, scopy, generic names. And the brand name was almost always the company name. And yet, in the past this naming strategy clearly worked. Why? Years ago the market was flooded with commodities produced by thousands of small companies operating in a single town or region. The big, scopy, generic names put these small competitors in their place.

13. The Law of the Company: brands are brands. Companies are companies. There is a difference. Consumers buy brands, they do not buy companies. When you combine a company name with a brand name in a clear and consistent fashion, the brand name is the primary name and the secondary name is seen as the company name.

With this caveat in mind, a company is a company as long as the name is not being used as a brand. Brand is a brand. There is a difference. A company is the organization that manufactures or produces the brand. It is not the brand itself.

14. The Law of Subbrands: what branding builds, subbranding can destroy. The essence of a brand is some singular idea, or attribute or market segment you can own in the mind. Subbranding is a concept that takes the brand in exactly the opposite direction. Subbranding destroys what branding builds. Branding concepts that are not driven by the marketplace are going to go nowhere. Subbranding, masterbranding, and megabranding are not costumer-driven concepts. 
15. The Law of Sibling: there is a time and place to launch a second brand. Laws of branding seem to suggest that a company concentrate all of its resources on single brand for a single market. A second brand strategy is not for every company. If handled incorrectly. The second brand can dilute the power of the first brand and waste resources. Yet, in some situations, a family of brands can be developed that will assure a company's control of a market for many decades to come. The key to a family approach is to make each sibling a unique individual brand with his or her own identity.

16. The Law of Shape: a brand's logotype should be designed to fit the eyes. Both eyes. A logotype is a combination of a trademark which is the visual symbol of the brand and the name of the brand set in distinctive type. Logotypes come in all shapes. The typefaces used to set the word can help or hinder the communication process, but only slightly. Legibility is the most important consideration in selecting a typeface used in a logotype.

17. The Law of Color: a brand should use a color that is the opposite of its major competitor. Another way to make a brand distinctive is with color. Basically there are five colors (red, orange, yellow, green and blue) plus the neutral colors (black, white and gray.) Make the brand's color the opposite of its major competitor.

18. The Law of Borders: there are no barriers to global branding. A brand should know no borders. In our consulting work we find that most clients strongly believe two things: first, their brands' market share cannot substantially increase in their home countries. Second, they need to grow.

The perfect solution to achieving both goals is to build a global brand. That means: keep the narrow focus in the home country. And then go global. For years the magic word on many brands has been 'imported'. In spite of duties, tariffs, import quotas, inspections, regulations, red tape, and petty harassments, the world is becoming one big global. And your brand had better get on the global bandwagon or you risk losing out altogether.

19. The Law of Consistency: a brand is not built overnight. Success is measured in decades, not years. Markets may change, but brands shouldn't. Ever. They may be bent slightly or given a new slant, but their essential characteristics (once those characteristics are firmly planted in the mind) should never be changed. Markets may change, but brands should stay the same.

20. The Law of Change: brands can be changed, but only infrequently and only very carefully. Companies are often focused on what they need to do internally in order to facilitate the change of a brand. But changing a brand does not occur inside a company. It occurs inside the mind of the consumer. If you want to change your brand, keep your sights on your target, the consumer's mind.

21. The Law of Mortality: no brand will live forever. Euthanasia is often the best solution. While the laws of branding are immutable, brands themselves are not. They are born, grow up, mature and eventually will die. 
There is a time to invest in a brand and there is a time to harvest a brand. And ultimately there is a time to put the brand to sleep.

22. The Law of Singularity: the most important aspect of a brand is its singlemindedness. Loss of singularity weakens a brand. What's a brand? A proper word that can be used in place of a common word. What's a brand? A singular idea or concept that you own inside the mind of the prospect. It's as simple and as difficult as that. 